\title{
Flexural Performance of Concrete Reinforced by Plastic Fibers
}

\author{
Muhammad Tahir Lakhiar \\ Faculty of Civil and Environmental \\ Engineering \\ Universiti Tun Hussein Onn Malaysia \\ Parit Raja, Johor, Malaysia \\ mtl.eng17@gmail.com
}

\author{
Nadeem-ul-Kareem Bhatti \\ Department of Civil Engineering \\ Quaid-e-Awam University of Engineering, \\ Science \& Technology \\ Nawabshah, Pakistan \\ knadeem_b@yahoo.com
}

\author{
Samiullah Sohu \\ Faculty of Civil and Environmental \\ Engineering \\ Universiti Tun Hussein Onn Malaysia \\ Parit Raja, Johor, Malaysia \\ sohoosamiullah@gmail.com
}

\author{
Suhail Ahmed Abbasi \\ Department of Civil Engineering \\ Quaid-e-Awam University of \\ Engineering, Science \& Technology \\ Nawabshah, Pakistan \\ abbasi.suhail2009@gmail.com
}

\author{
Imtiaz Ali Bhatti \\ Faculty of Civil and Environmental \\ Engineering \\ Universiti Tun Hussein Onn Malaysia \\ Parit Raja, Johor, Malaysia \\ Engrimtiaz290@gmail.com
}

\author{
Muhammad Tarique \\ Department of Civil Engineering \\ Mehran University of Engineering and \\ Technology \\ Jamshoro, Sindh, Pakistan \\ mtarique181@gmail.com
}

\begin{abstract}
For sustainable development construction, recycle or reuse of waste materials is utilized. Many researchers conducted tried to create an innovative green concrete, utilizing waste materials. The aim of this research is to contribute and promote the use of plastic waste in concrete. The concrete's flexural and workability were investigated by using different percentages of $0 \%, 0.2 \%, 0.4 \%, 0.6 \%, 0.8 \%$ and $1 \%$ of plastic fibers in concrete. In this study, M15 grade concrete beams were casted and cured for 7 and 28 days to analyze the flexural performance and workability. The outcomes demonstrated that the workability was slightly reduced by the utilizing plastic fibers where flexural strength improved by $16.5 \%$ at $0.6 \%$ addition of plastic fibers in concrete.
\end{abstract}

Keywords-flexural strength; workability; plastic fibers; green concrete

\section{INTRODUCTION}

Concrete is a material widely utilized in construction industry due to its many benefits. It is feasible, durable and economical compared to other building materials [1-3]. Flexural strength of concrete is minimum compared to compressive strength because concrete is brittle in nature [4]. To enhance the flexural strength, steel fibers are mostly used as reinforcement [5]. Steel contributes to the carbon dioxide $\mathrm{CO}_{2}$ emission in atmosphere during its manufacturing which contributes to global warming [6] and therefore, the need of sustainable green concrete raises day by day. Concrete made from waste, which is more eco-friendly, is known as green concrete. In other words, green concrete is the concrete in which waste materials are utilized in order to save natural resources and thus decrease environmental pollution. In this type of concrete, waste material is used to at replace least one of its ingredients. If its production process does not affect the environment, production procedures, life cycle sustainability and quantity of cement are the key factors adopted to categorize whether a concrete is green or not $[7,8]$. The main purpose of developing green concrete is to minimize $\mathrm{CO}_{2}$ gas emissions which cause environmental pollution and to re-use waste materials, which create disposal problems.

\section{MATERIALS AND METHODOLOGY}

\section{A. Materials}

For this experimental study, M15 grade concrete (1:2:4 ratio) was utilized with water-cement ratio constant at 0.55 . The material properties of fine and coarse aggregates and cement are shown in Tables I-III. Plastic fibers (Figure 1) were utilized from $0 \%-0.6 \%$ with increment of $0.2 \%$. Ordinary Portland cement was utilized for this research.

\section{B. Methodology}

M15 grade concrete was casted incorporating $0 \%-1 \%$ with increment of $0.2 \%$ of plastic fibers. Two concrete beam types were casted. One was conventional concrete beam which had $0 \%$ of plastic fibers (PF) and the other was plastic fiber concrete beam (PFC-B) which contained plastic fibers. Fifty four beams were casted, three beams were tested for each proportions at each curing age. The beams, having size $150 \mathrm{~mm} \times 200 \mathrm{~mm} \times 1500 \mathrm{~mm}$, were tested for flexural strength at different water curing regimes of 7, 14 and 28 days. Mixing was carried out utilizing a rotary mixer. The concrete mix workability was examined by standard slump test using standard slump cone and procedures according to ASTM C 143. All cubes were extracted from the molds after 24 hours and cured for the required age of testing. The concrete flexural 
strength was tested using three point flexural loading test. The ASTM followed the overall procedure described in ASTM C78/78M-18.

TABLE I. MATERIAL PROPERTIES OF FINE AGGREGATES

\begin{tabular}{|c|c|c|}
\hline S. No. & Test & Results \\
\hline 01 & Water absorption & $1.1 \%$ \\
\hline 02 & Specific gravity & 2.6 \\
\hline 03 & Finess modulus & 2.96 \\
\hline 04 & Color & Light brown \\
\hline
\end{tabular}

TABLE II. MATERIAL PROPERTIES OF COARSE AGGREGATES

\begin{tabular}{|c|c|c|}
\hline S. No. & Test & Results \\
\hline 01 & Water absorption & $1.19 \%$ \\
\hline 02 & Specific gravity & 2.68 \\
\hline 03 & Finess modulus & 6.15 \\
\hline
\end{tabular}

TABLE III. MATERIAL PROPERTIES OF CEMENT (O.P.C)

\begin{tabular}{|c|c|c|}
\hline S. No. & Test & Results \\
\hline 01 & Consistency & $31 \%$ \\
\hline 02 & Specific gravity & 3.14 \\
\hline 03 & Finess modulus & 1.18 \\
\hline
\end{tabular}

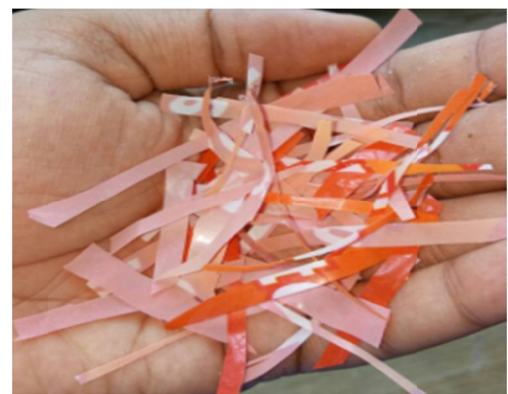

Fig. 1. Plastic fibers

\section{RESULTS AND DISCUSSION}

\section{A. Slump Test (ASTM C 143)}

ASTM C 143 standard [9] was fallowed to get the workability of concrete. Workability or slump flow results are shown in Table IV. The results show that the slump flow was slightly decreased incorporating the plastic fibers in concrete.

TABLE IV. SLUMP FLOW OF CONCRETE MIX.

\begin{tabular}{|c|c|}
\hline Mixtures & Slump Values(mm) \\
\hline Conventional Concrete Beam & 32.37 \\
\hline PFC-B $(0.2 \%$ PF) & 30.34 \\
\hline PFC-B $(0.4 \%$ PF) & 29.50 \\
\hline PFC-B $(0.6 \%$ PF) & 28.24 \\
\hline PFC-B $(0.8 \%$ PF) & 26.32 \\
\hline PFC-B (1\% PF) & 25.65 \\
\hline
\end{tabular}

\section{B. Flexural Strength of Beam}

Flexural strength test was performed according to the ASTM C78/78M-18 standard [10]. The flexural strength outcomes of all concrete mixes are shown in Table $\mathrm{V}$ and Figure 2. The outcomes demonstrated that beam flexural performance increased rapidly by utilizing plastic fibers up to
$0.8 \%$ and then it decreased slightly. After 7 days water curing, the flexural strength of PFC-B $11 \%$ increased up to $0.8 \%$ and decreased $1.5 \%$ when $1 \%$ of PF were utilized. After 14 days water curing, the flexural strength of PFC-B $15.23 \%$ increased rapidly up to $0.8 \%$ and decreased $1.42 \%$ when $1 \%$ of PF were utilized. After 28 days water curing, the flexural strength of PFC-B $16.52 \%$ increased rapidly up to $0.8 \%$ and decreased $2.54 \%$ when $1 \%$ of PF were utilized.

TABLE V. FLEXURAL STRENGTH OF CONCRETE

\begin{tabular}{|c|c|c|c|}
\hline \multirow{2}{*}{ Mixtures } & \multicolumn{3}{|c|}{ Flexural Strength (MPA) } \\
\cline { 2 - 4 } & 7 days & 14 days & 28 days \\
\hline Conventional Concrete Beam & 1.96 & 2.10 & 2.36 \\
\hline PFC-B (0.2\% PF) & 2.08 & 2.26 & 2.57 \\
\hline PFC-B (0.4\% PF) & 2.13 & 2.32 & 2.68 \\
\hline PFC-B (0.6\% PF) & 2.18 & 2.42 & 2.75 \\
\hline PFC-B (0.8\% PF) & 2.15 & 2.35 & 2.65 \\
\hline PFC-B (1\% PF) & 1.93 & 2.07 & 2.30 \\
\hline
\end{tabular}

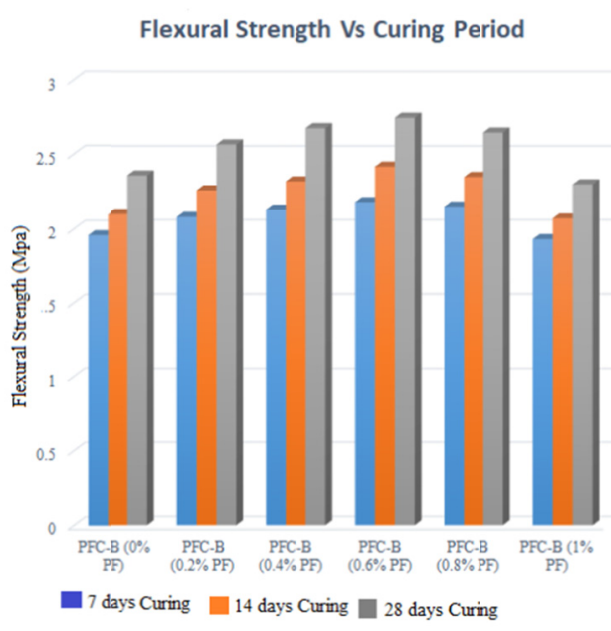

Fig. 2. Flexural strength outcomes of all mixes

\section{CONCLUSION}

The workability of concrete slightly reduced when consist plastic fibers were added because of the fibers' resistance to flow. The flexural strength increased up to $16.5 \%$ compared to the control sample. The optimum percentage of fibers was found to be $0.6 \%$ and it enhanced the flexural performance of concrete in context of all other mixes.

\section{REFERENCES}

[1] M. T. Lakhiar, N. Mohamad, M.A. B. Shaikh, A. A. Vighio, A. A Jhatial, A. A. Abdul Samad, "Efffect of River Indus Sand on Concrete Tensile Strength", Engineering Technlogy \& Applied Science Research, Vol. 8, No. 2, pp. 2796-2798, 2018

[2] Z. Li, Advanced Concrete Technology, John Wiley and Sons Inc., 2011

[3] A. M. Neville, Properties of Concrete, Prentice Hall, 2011

[4] R. Nagalakshmi, "Experimental study on strength characteristics on M25 concrete with partial replacement of cement with fly ash and coarse aggregate with coconut shell", International Journal of Scientific \& Engineering Research, Vol. 4, No. 1, 2013

[5] E. Mello, C. Ribellato, E. Mohamedelhassan, "Improving Concrete Properties with Fibers Addition", International Journal of Civil and Environmental Engineering, Vol. 8, No. 3, pp. 249-254, 2014 
[6] Y. Wang, Q. Wang, Y. Hang, Z. Zhao, S. Ge, " $\mathrm{CO}_{2}$ emission abatement cost and its decomposition: A directional distance function approach", Journal of Cleaner Production, Vol. 115, pp. 205-215, 2018

[7] A. Baikerikar, "A Review on Green Concrete", J. Emerging Technol. Innovative Res. Vol.1, No.6, pp. 472-474, 2014.

[8] K. H. Obla, "What is Green Concrete?", The Indian Concrete Journal, Vol. 24, pp. 26-28, 2009

[9] ASTM International, ASTM C143/C143M-15, Standard Test Method for Slump of Hydraulic-Cement Concrete), ASTM International, West Conshohocken, PA, 2015

[10] ASTM International, ASTM C78/78M-18, Standard Test Method for Flexural Strength of Concrete (Using Simple Beam with Third-Point Loading), ASTM International, West Conshohocken, PA, 2018 